\title{
THE
}

\section{Hemlock Woolly Adelgid Alters Fine Root Bacterial Abundance and Mycorrhizal Associations in Eastern Hemlock}

\author{
Justin F. Vendettuoli \\ David A. Orwig \\ Jennifer Adams Krumins \\ Matthew D. Waterhouse \\ Evan L. Preisser \\ University of Rhode Island, preisser@uri.edu
}

Follow this and additional works at: https://digitalcommons.uri.edu/bio_facpubs

The University of Rhode Island Faculty have made this article openly available.
Please let us know how Open Access to this research benefits you.

This is a pre-publication author manuscript of the final, published article.

Terms of Use

This article is made available under the terms and conditions applicable towards Open Access Policy Articles, as set forth in our Terms of Use.

\section{Citation/Publisher Attribution}

JF Vendettuoli, DA Orwig, J Adams Krumins, MD Waterhouse, and EL Preisser. (2015). "Hemlock woolly adelgid alters fine root bacterial abundance and mycorrhizal associations in eastern hemlock." Forest Ecology and Management. 339: 112-116. Available at: http://www.sciencedirect.com/science/article/pii/ S0378112714007178. 
Running head: Underground effects of adelgid

2

TITLE: Hemlock woolly adelgid alters fine root bacterial abundance and mycorrhizal

$4 \quad$ associations in eastern hemlock

5

6 Justin F. Vendettuoli ${ }^{1}$, David A. Orwig ${ }^{2}$, Jennifer Adams Krumins ${ }^{3}$, Matthew D.

$7 \quad$ Waterhouse ${ }^{4}$, and Evan L. Preisser ${ }^{5^{*}}$

8

$9 \quad{ }^{1}$ Department of Natural Resources Science, University of Rhode Island, Kingston, RI

$10 \quad 02881$

$11 \quad{ }^{2}$ Harvard Forest, Harvard University, Petersham MA 01366

$12{ }^{3}$ Department of Biology and Molecular Biology, Montclair State University, Montclair

13 NJ 07043

$14{ }^{4}$ Department of Biology, University of British Columbia, Kelowna BC V1V 1V7

$15 \quad{ }^{5}$ Department of Biological Sciences, University of Rhode Island, Kingston RI 02881

16

17 *Corresponding author: Evan Preisser

18 Department of Biological Sciences, University of Rhode Island, Kingston RI 02881

19 Ph: 401-874-2120 e-mail: preisser@uri.edu

20

KEYWORDS

22 Adelges tsugae, Tsuga canadensis, mycorrhizae, fine root bacteria, fine root

23 carbon:nitrogen 


\section{ABSTRACT}

25 While the impact of aboveground herbivores on plant biomass and fitness has received

26 considerable attention, there has been far less research on the corresponding belowground

27 impacts. The belowground effects of aboveground feeding may be particularly noticeable for

28 invasive and/or outbreaking herbivore species that reach high densities and can cause major

29 damage and sometimes death. The hemlock woolly adelgid, Adelges tsugae, is an invasive pest

30 on the eastern seaboard of the United States that feeds on a native shade-tolerant conifer, the

31 eastern hemlock Tsuga canadensis. Trees rapidly decline and die following infestation, and the

32 invasion of this insect has devastated hemlock populations from Georgia in the south to Maine in

33 the north. Despite their substantial impact on tree health, we are unaware of any research into the

34 adelgid's effect on hemlock roots and the surrounding rhizosphere. We report the results of

35 research assessing ectomycorrhizal root colonization, rhizosphere bacterial abundance, and root

36 C:N ratios of infested and uninfested T. canadensis. We found that adelgid infestation decreased

37 the percentage of root material colonized by ectomycorrhizal fungi by more than $67 \%$.

38 Rhizosphere bacterial abundance on fine roots was $25 \%$ lower on adelgid-infested versus

39 uninfested trees, and roots of adelgid-infested trees contained significantly less carbon. Our

40 results demonstrate that aboveground adelgid infestation can affect hemlock root composition

41 and alter belowground interactions with ectomycorrhizal fungi and bacteria. This information

42 demonstrates that above-belowground linkages can transmit the impact of herbivory far from the

43 site of localized damage.

\section{$44 \quad$ 1.0 INTRODUCTION}

45 The impact of insect herbivores on plant growth and community structure can range from

46 inconsequential to major; in extreme cases the structure and functions of entire ecosystems can 
47 be substantially altered (Lovett et al., 2006). In some instances, insect herbivores can increase

48 biodiversity via preferential feeding on dominant species, allowing resources to be exploited by a

49 greater number of species (Carson and Root, 2000). In other cases where herbivores inflict

50 substantial damage, outbreaks of such species can devastate their hosts and cause major changes

51 to the environment (Smith and Schowalter, 2001; Gandhi and Herms, 2010) and economic loss

52 (Aukema et al., 2011; Oliveira et al., 2013).

53 Researchers are increasingly aware that herbivore grazing on aboveground green biomass

54 can have profound belowground impacts on the composition of organisms and subsequent

55 nutrient cycling in the rhizosphere (Bardgett and Wardle, 2010). The herbivore removal of

56 aboveground plant tissue can alter patterns of carbon and nutrient allocation in belowground

57 roots (Rasmann et al., 2009). This can affect the composition and abundance of rhizosphere-

58 dwelling organisms. Cattle grazing, for instance, has been shown to alter microbial community

59 composition and food web structure in the root zone of grass (Hamilton and Frank, 2001; Veen

60 et al., 2010). Moose and snowshoe hare grazing have also led to reduced ectomycorrhizal (EM)

61 colonization in roots of balsam poplar (Populus balsamifera) and willow (Salix spp.) (Rossow et

62 al., 1997). These changes can in turn alter rates of nutrient cycling and availability in ways that

63 affect the grazed plant. This feedback loop has been well-documented and can be surprisingly

64 favorable for plant growth and recovery (Ruess and McNaughton, 1987; Krumins, 2014).

65 While the effect of folivory on aboveground-belowground interactions has been well-

66 studied in herbaceous plants, the impact of sap-feeding herbivores on aboveground-belowground

67 interactions in woody plant species has attracted less attention. This gap is notable in light of

68 work documenting that sap-feeder impacts on woody plant fitness equal or exceed those of

69 folivores (Zvereva et al., 2010). Aphid infestations, for instance, indirectly reduce root growth in 
70 Sitka spruce by limiting the tree's ability to provide carbon from photosynthesis (Day and

71 Cameron, 1997) and reduce root tissue density of Douglas fir by inducing the translocation of

72 additional carbohydrates from roots to shoots (Smith and Schowalter, 2001). Herbivory by the

73 needle-feeding scale Matsucoccus acalyptus reduced EM colonization of pinyon pine (Gehring

74 and Whitham, 1991); similarly, western spruce budworm (Choristoneura occidentalis)

75 defoliation reduced EM colonization in Douglas fir seedlings (Kolb et al., 1999). More

76 generally, both folivores and sap feeders can also impact epiphytic microbial communities

77 through their production of nutrient-rich excrement (Stadler et al., 2001).

78 The hemlock woolly adelgid (Adelges tsugae; 'adelgid') is an invasive sessile herbivore

79 that feeds exclusively on eastern hemlock (Tsuga canadensis (L.) Carr.) in the northeastern

80 United States. While it has minimal impact on hemlock health in its native range of Japan and

81 China (Havill et al., 2006), it can kill even mature eastern hemlocks in as little as four years; few

82 heavily-infested trees survive longer than ten years (Orwig and Foster, 1998). While the impact

83 of the adelgid on hemlock physiology has been studied (Radville et al., 2011; Gómez et al.,

84 2012; Gonda-King et al., 2012; Domec et al., 2013), its effects on hemlock root physiology and

85 the associated rhizosphere remain unexplored.

86 We report the results of work exploring the belowground impact of adelgid infestation on

87 T. canadensis. We measured root EM associations of infested and uninfested hemlock trees,

88 rhizosphere bacterial abundance, and root $\mathrm{C}: \mathrm{N}$ ratios. Our findings demonstrate that

89 aboveground adelgid infestation of eastern hemlock has belowground consequences that likely

90 augment the ecosystem-level impact of this pest and may need to be addressed for the maximal

91 success of forest restoration efforts.

$92 \quad 2.0$ METHODS 
As part of a long-term research program addressing the impacts of the hemlock woolly

94 adelgid on eastern hemlock, we characterized adelgid infestation level and stand vigor in 79

95 stands in CT and 63 stands in MA. Following their initial characterization (1997-1998 in CT,

96 2002-2004 in MA; Orwig et al., 2002; Orwig et al., 2012), these stands were repeatedly surveyed

97 for adelgid infestation and stand vigor in 2005, 2007, 2009, and 2011 (Preisser et al., 2008;

98 Preisser et al., 2011). We assessed the rhizosphere of eastern hemlocks in a subset of the stands

99 described above. In order to explore how adelgid infestation affects rhizosphere processes in

100 eastern hemlock, we characterized both fine-root EM colonization (Study \#1) and bacterial

101 abundance (Study \#2).

102 In Study \#1, we quantified EM colonization of hemlock roots in three adelgid-infested

103 and two uninfested hemlock stands in 2003; we focused our research on ectomycorrhizae as

104 opposed to arbuscular (endo) mycorrhizae because conifers like hemlock are almost exclusively

105 colonized by ectomycorrhizae (Smith et al., 1997). Infested stands were located in south-central

106 Connecticut, and had been colonized by adelgid for 3-10 years; uninfested forests were located

107 in central Massachusetts (Fig. 1). In Study \#2, we quantified rhizosphere bacterial abundance

108 from ten infested and ten uninfested hemlock stands in central and northern Massachusetts in

1092013 (Fig. 1). In both studies, trees sampled in the 'infested' treatment were heavily infested

110 themselves (>1 mature adelgid/cm foliage growth) and surrounded by other heavily-infested

111 trees. In contrast, trees sampled in the 'uninfested' treatments were in stands where no adelgid

112 had been detected during previous large-scale surveys; to ensure that the sampled trees had

113 maintained their uninfected status, we carefully surveyed each sampled tree and all trees within

$11410 \mathrm{~m}$ of it to ensure the absence of adelgid. Because of logistical constraints, we were unable to

115 sample the same sites in both surveys. Regardless of location, all sampled stands consisted of 
$116>50 \%$ hemlock canopy cover within 100m of the sampled trees, and 100\% canopy cover within

$11710 \mathrm{~m}$ of the sampled trees.

118

119

120

121 and stand traits were sampled in the course of several related studies (Cobb et al., 2006; Orwig et

122 al., 2013); infested sites averaged $708 \pm 19[\mathrm{SE}]$ trees ha $^{-1}$, with a mean hemlock stand basal area

123 of $46.6 \pm 2.7 \mathrm{~m}^{2} \mathrm{ha}^{-1}$; uninfested sites averaged $1072 \pm 97$ [SE] trees ha ${ }^{-1}$, with a mean hemlock

124 stand basal area of $45.6 \pm 2.0 \mathrm{~m}^{2} \mathrm{ha}^{-1}$. soils in infested sites had a mean organic (forest floor) soil

125 C:N ratio of $26.1 \pm 2.3 \%$ [SE] and a mean mineral soil c: $n$ ratio of $23.2 \pm 0.65 \%$. Soils in

126 uninfested sites had a organic (forest floor) soil C:N ratio of $26.9 \%$ and a mineral soil c:n ratio of

$12724.1 \%$ (also see online appendix \#1). Only trees growing under a hemlock-dominated canopy

128 were sampled. Each sapling was uprooted to expose the entire root system, and three $20 \mathrm{~cm}$ root

129 samples per tree were collected and rinsed with deionized water (four of 30 sampled trees only

130 had sufficient roots for two $20 \mathrm{~cm}$ root samples). Although we would have liked to sample mature

131 trees, the labor involved in uprooting multiple large hemlock trees (necessary to ensure that the

132 sampled roots in fact belonged to the chosen tree) necessitated using saplings. Each root sample

133 was assigned a random number to ensure an unbiased assessment and then trimmed down to a

$1345 \mathrm{~cm}$ section. The grid intercept method (Giovanetti and Mosse, 1980) was used to assess the

135 percent EM colonization for each root sample. Roots with EM colonization were differentiated

136 on the basis of morphology, color, characteristics of the surface of the hyphal mantle, and planar

137 views of different mantle layers using standard methods (Agerer, 1992). Each root sample was

138 randomly dispersed in a $9 \mathrm{~cm}$ diameter petri plate with $0.5 \mathrm{~cm}$ grid lines. The intersection between 
139 grid lines and roots were designated as either EM-colonized or non-mycorrhizal. The proportion

140 of root counts that were mycorrhizal was calculated for each root sample and averaged for each

141 sapling. We took a total of 5,902 counts, an average of 197 counts per tree (each tree had a

142 minimum of 100 counts).

$143 \quad 2.2$ Study 2: Bacterial abundance in the rhizosphere

144 We collected fine roots $(\leq 2 \mathrm{~mm}$ diameter; Robertson et al., 1999) from three understory

145 hemlocks (2 $-5 \mathrm{~m}$ tall) at each of twenty sites (10 infested and 10 uninfested); all sampled trees

146 were growing under a hemlock-dominated canopy. Again, our choice of the sampled trees was

147 motivated by the difficulties inherent in uprooting multiple large hemlock trees (necessary to

148 ensure that the sampled roots in fact belonged to the chosen tree). Infested sites averaged $1312 \pm$

$149240[\mathrm{SE}]$ trees ha ${ }^{-1}$, with a mean hemlock basal area of $33.2 \pm 1.5 \mathrm{~m}^{2} \mathrm{ha}^{-1}$; uninfested sites

150 averaged $859 \pm 78[\mathrm{SE}]$ trees ha ${ }^{-1}$, with a mean hemlock basal area of $38.2 \pm 1.7 \mathrm{~m}^{2} \mathrm{ha}^{-1}$. Soils in

151 infested sites had a mean organic (forest floor) soil C:N ratio of $26.9 \pm 1.4 \%$ [SE] and a mean

152 mineral soil c: $n$ ratio of $24.5 \pm 2.0 \%$. Soils in uninfested sites had a mean organic soil C:N ratio

153 of $28.8 \pm 1.6 \%$ and a mean mineral soil c: $n$ ratio of $24.5 \pm 1.6 \%$ (also see online appendix \#1; for

154 a more detailed site description, see Orwig et al., 2012). Roots were collected from each

155 hemlock by lightly scraping away leaf litter and organic soil from the base of the tree, extracting

156 the roots, and clipping three $12-15 \mathrm{~cm}$ root samples. Root samples were combined in a single

157 plastic bag (one bag per tree), immediately returned to the lab, and refrigerated for $<2$ hours prior

158 to fixation. Before fixing each sample, loose debris and soil was manually shaken off; $\sim 0.1 \mathrm{~g}$ of

159 fine roots from each tree was then placed in $5 \mathrm{~mL}$ of phosphate buffer saline (PBS) solution and

160 vortexed for 2 minutes to suspend the bacteria. Each suspension was fixed with $1.5 \%$ filtered 
161 formalin (1.5\% final formalin concentration) and again vortexed. Fixed samples were stored at

$162 \quad 4^{\circ} \mathrm{C}$ prior to staining and enumeration.

163 Staining took place within three days of the sample being fixed and collected; because the

164 samples were fixed immediately after collection, there were no time-related differences between

165 bacterial counts taken on different days. Bacterial abundance was determined using acridine

166 orange direct counts (AODC) (Kepner and Pratt, 1994). Cell concentration was optimized by

167 dilution to achieve countable samples. Between $0.1-0.5 \mathrm{ml}$ of each fixed sample was removed

168 (the extracted amount was supplemented with PBS to ensure a total volume of $1 \mathrm{ml}$ ) and then

169 stained with $200 \mu \mathrm{l}$ of $0.1 \%$ acridine orange. Each sample was vacuum-captured onto a $0.2 \mu \mathrm{m}$

170 black polycarbonate filter (EMD Millipore Corporation, MA) and fixed to a slide with

171 immersion oil. Enumeration was done using a Nikon Eclipse Ti inverted fluorescent microscope

172 fixed with a Nikon DS-Fi1 camera. We determined mean bacterial abundance per slide by

173 photographing ten randomly-chosen locations on each slide, using ImageJ (Schneider et al.

174 2012) to count bacterial densities, and averaging the ten counts. Each count thus reflects the

175 mean number of cells per $\mathrm{g}$ fresh weight of plant material. Because the extraction procedures

176 involved washing and removing fresh plant tissue, we could not calculate the dry weight of plant

177 material.

178 We used the procedures outlined above to collect an additional fine root sample in 2013

179 for carbon and nitrogen analysis from each tree used for bacterial abundance at the 20 sites. Fine

180 roots were rinsed with deionized water to remove soil particles and dried at $60^{\circ} \mathrm{C}$ in an oven for

$18148 \mathrm{hrs}$. Dried samples were ground into a fine powder using a grinding mill (Spex Mixer Mill

$1828000 \mathrm{M}$, Metuchen, NJ) and analyzed for carbon and nitrogen content with a nutrient analyzer 
183 (Elementar vario MICRO cube, Mount Laurel, NJ). Two replicates of each fine root sample were

184 analyzed, and the results averaged to calculate a site-level mean.

1852.3 Statistical Analysis: To test the effect of adelgid infestation on EM colonization,

186 bacterial abundance, and root C:N, all samples were grouped by site and the infested and control

187 sites were compared. Because the data from Study \#1 did not meet the assumptions of normality,

188 we analyzed it using a non-parametric median test; data from Study \#2 was analyzed using one-

189 way ANOVA. EM colonization was calculated as percent colonization and bacterial abundance

190 was calculated as number of cells per gram fresh weight of root. All analyses were performed

191 using JMP 9.0 (SAS, Cary, NC).

\section{$192 \quad 3.0$ RESULTS}

193 The percentage of EM colonization was significantly lower $(10.6 \pm 2.4 \%$ [SE] $)$ on infested

194 hemlock roots compared to roots from uninfested trees $(32.4 \pm 10.2 \%)$ (Median Test; $\mathrm{p}=0.046)$.

195 Hemlock fine root bacterial abundance, measured in millions of cells per gram, was also lower

196 on infested versus uninfested trees $\left(\mathrm{F}_{1,18}=2.22\right.$, $\mathrm{p}=0.044$; Fig. 2A). Chemical analysis of fine

197 roots from adelgid-infested versus uninfested trees revealed that percent carbon was significantly

198 lower in infested hemlock stands $\left(\mathrm{F}_{1,18}=5.11, \mathrm{p}=0.036\right.$; Fig. $\left.2 \mathrm{~B}\right)$, but that adelgid infestation did

199 not affect percent nitrogen (Fig. 2C). Despite the differences in root C, roots from infested versus

200 uninfested stands did not differ in their root C:N ratio (Fig. 2D).

\subsection{DISCUSSION}

We found that aboveground infestation by hemlock woolly adelgid significantly affected

203 rhizosphere processes. The rhizosphere surrounding fine roots of adelgid-infested trees had less

204 ectomycorrhizal colonization and lower bacterial abundance (Fig. 2A), while the fine roots

205 themselves had lower carbon concentrations (Fig. 2B). The lower percentage of ectomycorrhizal 
206 colonization found in our results is consistent with findings following herbivory from several

207 types of insects (Gehring and Whitham, 1994b). One of the most common causes of decreased

208 ectomycorrhizal colonization is herbivory-driven reductions in photosynthate availability; this

209 can disrupt carbohydrate supply to mycorrhizae and reduce mycorrhizal root tip abundance

210 (Gehring and Whitham, 1994b) and mycorrhizal inoculum potential (Lewis et al., 2008). Aphid

211 outbreaks on other conifer species, for instance, can decrease photosynthetic efficency (Day and

212 Cameron, 1997). The hemlock woolly adelgid has been shown to cause similar reductions in

213 photosynthesis (Nelson et al., 2014), and continued feeding on hemlock likely leads to

214 continuous carbohydrate depletion. It is possible that the reduction in carbon found in the fine

215 roots of infested trees (Fig. 2B) and lower EM colonization result from a disruption of that

216 carbon source.

217 Environmental conditions can also play a significant role in the mycorrhizal response to

218 herbivory (Bardgett and Wardle, 2003; Gehring and Whitham, 2003). There has been a

219 documented decrease in EM colonization in sites with higher soil nutrient status compared with

220 water- and nutrient-stressed sites (Gehring and Whitham, 1994a). Several environmental

221 characteristics of chronic HWA infestation may have impacted the EM colonization response

222 seen in this study. First, Stadler et al. $(2005 ; 2006)$ provided evidence that adelgid impacts the

223 composition of throughfall in infested stands. Their work showed higher inputs of $\mathrm{N}$ into the soil

224 under adelgid-infested trees. Second, in addition to inputs from throughfall, adelgid damage

225 often yields microenvironmental conditions that lead to increased soil $\mathrm{N}$ due to changes in

226 decomposition, $\mathrm{N}$ cycling and availability, and reduced tree uptake of nutrients (Kizlinski et al.

227 2002; Orwig et al. 2008). Enhanced soil N status resulting from either of these mechanisms may

228 also have led to reduced colonization of hemlock fine roots and associated bacterial levels. 
229 Finally, altered mycorrhizal community structure resulting from increased $\mathrm{N}$ in the system may

230 have selected for ectomycorrhizal species that perform less of a service for their host but still

231 require the same carbon cost (Johnson, 1993).

232 We expected the abundance of bacterial cells colonizing the roots of adelgid-infested

233 trees to be higher. Experiments in grasslands ecosystems showed that grazed plants exude more

234 carbon into the rhizosphere, thus stimulating microbial growth and metabolism (Hamilton and

235 Frank, 2001). The priming effect (Kuzyakov et al., 2000) stimulated by above-ground herbivory

236 fed back positively to the grasses, increasing nutrient availability. Rhizosphere microbes have the

237 primary responsibility for making nutrients available to plants through the decomposition and

238 mineralization of soil organic matter (Vessey, 2003). It is interesting to note that we did not find

239 increased microbial abundance in the trees we studied. This difference may be due to important

240 differences in the feeding behavior of herbivores and how they affect the host plant (Lovett et al.,

241 2006). Sucking insects, for instance, export far less wasted plant biomass (inreasing soil organic

242 matter) and frass to the forest floor than do chewing insects or larger grazers (Zvereva et al.,

243 2010).

244 Bacterial and fungal communities are often tightly coupled in the rhizosphere. The

245 reduced bacterial abundance found in adelgid-infested hemlock stands may simultaneously be

246 linked to reduced ectomycorrhizal associations and changes in root and soil nutrient chemistry

247 associated with infestation. Indeed, some studies have found that soil communities experiencing

248 mycorrhizal loss also lose their fungally-associated bacteria (Hol et al., 2014). However, the

249 significant decline in absolute numbers of bacteria suggests resource limitation from the root.

250 The implications of decreased bacterial load will be decreased mineral nutrient availability to the

251 tree (Vessey, 2003; Wardle et al., 2004); this is consistent with our results (Fig. 2A). Knowing 
252 both the load of EM and bacteria in the rhizosphere is, however, only the first critical step. Soil

253 communities are classically divided into bacterial- and fungal-based energy channels (Moore and

254 Hunt, 1988; De Ruiter et al., 1995). It is the balance of these two energetic pathways, however,

255 that leads to stability and functioning of the rhizosphere community (Rooney et al., 2006) and

256 overall plant health. Therefore, future work will test differences in community composition of

257 both mycorrhiza and bacteria colonizing the roots of trees in affected and unaffected sites. The

258 reduced colonization by EM and bacterial abundance found here may be caused by strong

259 competitors dominating the rhizosphere community.

260 Our work provides the first documentation of the below-ground consequences of above-

261 ground herbivory on eastern hemlock by an exotic herbivore. The impact of aboveground

262 feeding by the hemlock woolly adelgid on the rhizosphere processes of the hemlock and the

263 mycorrhizal and bacterial abundances illustrates the need for a greater understanding of how

264 herbivores impact all aspects of an ecosystem. From a management perspective, there is

265 increased recognition (Kardol and Wardle, 2010) of the importance of aboveground-

266 belowground linkages in determining the efficacy of management and restoration efforts.

267 Specifically, adelgid-mediated alterations in the belowground communities that facilitate

268 hemlock growth could make it more difficult to replant hemlocks in formerly-suitable areas.

269 Further research should investigate the soil community structure of infested hemlock stands

270 against uninfested hemlock stands, to see if there are shifts in the species found in addition to the

271 change in abundance of bacteria.

\subsection{ACKNOWLEDGEMENTS}

273 We thank M. Patel for her assistance with the lab work and C. Renaud for help

274 processing samples. The manuscript was greatly improved by by the comments and suggestions 
275 of two anonymous reviewers. This work was funded by RI00HI-4004 to EP, NIFA 2011-67013-

27630142 to EP and DO, NSF funding through its programs in Research Experience for

277 Undergraduates (DBI 10-03938), Long Term Ecological Research (DEB 12-37491), and is a

278 publication of the Harvard Forest Long Term Ecological Research (LTER) Site.

$279 \quad 6.0$ LITERATURE CITED

280 Agerer, R., 1992. Ectomycorrhizae of Phellodon niger on Norway spruce and their

281 chlamydospores. Mycorrhiza 2, 47-52.

282 Aukema, J., Leung, B., Kovacs, K., Chivers, C., Britton, K., Englin, J., Frankel, S., Haight, R.,

283 Holmes, T., Liebhold, A., McCullough, D., Von Holle, B., 2011. Economic impacts of non-

284 native forest insects in the continental United States. PLoS ONE 6, e24587.

285 Bardgett, R.D., Wardle, D.A., 2003. Herbivore-mediated linkages between aboveground and

286 belowground communities. Ecology 84, 2258-2268.

287 Bardgett, R.D., Wardle, D.A., 2010. Aboveground-Belowground Linkages: Biotic Interactions,

288 Ecosystem Processes, and Global Change. Oxford University Press.

289 Carson, W.P., Root, R.B., 2000. Herbivory and plant species coexistence: community regulation

290 by an outbreaking phytophagous insect. Ecol Monogr 70, 73-99.

291 Cobb, R., Orwig, D., Currie, S., 2006. Decomposition of green foliage in eastern hemlock forests

292 of southern New England impacted by hemlock woolly adelgid populations. Can. J. For. Res. 36, 293 1331-1341.

294 Day, K.R., Cameron, A., 1997. Effect of contemporary infestation by the spruce aphid

295 (Elatobium abietinum) on root growth in Sitka spruce transplants. Forestry 70, 1-5.

296 De Ruiter, P., Neutel, A.-M., Moore, J.C., 1995. Energetics, patterns of interaction strengths, and 297 stability in real ecosystems. Science 269, 1257-1260. 
298 Domec, J.-C., Rivera, L.N., King, J.S., Peszlen, I., Hain, F., Smith, B., Frampton, J., 2013.

299 Hemlock woolly adelgid (Adelges tsugae) infestation affects water and carbon relations of

300 eastern hemlock (Tsuga canadensis) and Carolina hemlock (Tsuga caroliniana). New Phytol

$301 \quad 199,452-463$.

302 Gandhi, K., Herms, D., 2010. Direct and indirect effects of alien insect herbivores on ecological

303 processes and interactions in forests of eastern North America. Biol. Invasions 12, 389-405.

304 Gehring, C.A., Whitham, T.G., 1991. Herbivore-driven mycorrhizal mutualism in insect-

305 susceptible pinyon pine. Nature 353, 556-557.

306 Gehring, C.A., Whitham, T.G., 1994a. Comparisons of ectomycorrhizae on pinyon pines (Pinus

307 edulis; Pinaceae) across extremes of soil type and herbivory. Am. J. Bot. 81, 1509-1516.

308 Gehring, C.A., Whitham, T.G., 1994b. Interactions between aboveground herbivores and the 309 mycorrhizal mutualists of plants. Trends Ecol Evol 9, 251-255.

310 Gehring, C.A., Whitham, T.G., 2003. Mycorrhizae-Herbivore Interactions: Population and

311 Community Consequences. In: van der Heijden, M.G.A., Sanders, I.R. (Eds.), Mycorrhizal

312 Ecology. Springer Berlin Heidelberg, pp. 295-320.

313 Giovanetti, M., Mosse, B., 1980. An evaluation of techniques for measuring vesicular-arbuscular

314 mycorrhizal infection in roots. New Phytol 84, 489-500.

315 Gómez, S., Orians, C., Preisser, E., 2012. Exotic herbivores on a shared native host: tissue

316 quality after individual, simultaneous, and sequential attack. Oecologia 169, 1015-1024.

317 Gonda-King, L., Radville, L., Preisser, E., 2012. False ring formation in eastern hemlock

318 branches: impacts of hemlock woolly adelgid and elongate hemlock scale. Environ Entomol 41, $319 \quad 523-531$. 
320 Hamilton, E.W., Frank, D.A., 2001. Can plants stimulate soil microbes and their own nutrient

321 supply? Evidence from a grazing tolerant grass. Ecology 82, 2397-2402.

322 Havill, N., Montgomery, M., Yu, G., Shiyake, S., Caccone, A., 2006. Mitochondrial DNA from

323 hemlock woolly adelgid (Hemiptera: Adelgidae) suggests cryptic speciation and pinpoints the

324 source of the introduction to eastern North America. Ann. Entomol. Soc. Am. 99, 195-203.

325 Hol, W.H.G., de Boer, W., Medina, A., 2014. Beneficial Interactions in the Rhizosphere. In:

326 Dighton, J., Krumins, J.A. (Eds.), Interactions in Soil: Promoting Plant Growth. Springer

327 Netherlands, pp. 59-80.

328 Johnson, N.C., 1993. Can fertilization of soil select less mutualistic mycorrhizae? Ecol. Appl. 3, $329 \quad 749-757$.

330 Kardol, P., Wardle, D.A., 2010. How understanding aboveground-belowground linkages can 331 assist restoration ecology. Trends Ecol Evol 25, 670-679.

332 Kepner, R.L., Pratt, J.R., 1994. Use of fluorochromes for direct enumeration of total bacteria in

333 environmental samples: past and present. Microbiol Rev 58, 603-615.

334 Kolb, T.E., Dodds, K.A., Clancy, K.M., 1999. Effect of western spruce budworm defoliation on

335 the physiology and growth of potted Douglas-fir seedlings. For Sci 45, 280-291.

336 Krumins, J.A., 2014. The Positive Effects of Trophic Interactions in Soil. In: Dighton, J.,

337 Krumins, J.A. (Eds.), Interactions in Soil: Promoting Plant Growth. Springer Netherlands, pp. 338 81-94.

339 Kuzyakov, Y., Friedel, J.K., Stahr, K., 2000. Review of mechanisms and quantification of 340 priming effects. Soil Biol. Biochem. 32, 1485-1498. 
341 Lewis, J., Licitra, J., Tuininga, A., Sirulnik, A., Turner, G., Johnson, J., 2008. Oak seedling

342 growth and ectomycorrhizal colonization are less in eastern hemlock stands infested with

343 hemlock woolly adelgid than in adjacent oak stands. Tree Physiology 28, 629-636.

344 Lovett, G.M., Canham, C.D., Arthur, M.A., Weathers, K.C., Fitzhugh, R.D., 2006. Forest

345 ecosystem responses to exotic pests and pathogens in eastern North America. Bioscience 56,

$346 \quad 395-405$.

347 Moore, J.C., Hunt, H.W., 1988. Resource compartmentation and the stability of real ecosystems.

348 Nature 333, 261-263.

349 Nelson, L.A., Dillaway, D.N., Rieske, L.K., 2014. Effect of an exotic herbivore, Adelges tsugae,

350 on photosynthesis of a highly susceptible Tsuga host, with notes on conspecifics. Arthropod-

351 Plant Interactions 8, 9-15.

352 Oliveira, C.M., Auad, A.M., Mendes, S.M., Frizzas, M.R., 2013. Economic impact of exotic

353 insect pests in Brazilian agriculture. J Appl Entomol 137, 1-15.

354 Orwig, D., Foster, D., 1998. Forest response to the introduced hemlock woolly adelgid in

355 southern New England, USA. J Torrey Bot Soc 125, 60-73.

356 Orwig, D., Foster, D., Mausel, D., 2002. Landscape patterns of hemlock decline in New England 357 due to the introduced hemlock woolly adelgid. J Biogeogr 29, 1475-1487.

358 Orwig, D., Plotkin, A., Davidson, E., Lux, H., Savage, K., Ellison, A., 2013. Foundation species

359 loss affects vegetation structure more than ecosystem function in a northeastern USA forest.

360 PeerJ 1, e41.

361 Orwig, D., Thompson, J., Povak, N., Manner, M., Niebyl, D., Foster, D., 2012. A foundation tree 362 at the precipice: Tsuga canadensis health after the arrival of Adelges tsugae in central New

363 England. Ecosphere 3, 10. 
364 Preisser, E., Lodge, A., Orwig, D., Elkinton, J., 2008. Range expansion and population dynamics

365 of co-occurring invasive herbivores. Biol. Invasions 10, 201-213.

366 Preisser, E., Miller-Pierce, M., Vansant, J., Orwig, D., 2011. Eastern hemlock (Tsuga

367 canadensis) regeneration in the presence of hemlock woolly adelgid (Adelges tsugae) and

368 elongate hemlock scale (Fiorinia externa). Can. J. For. Res. 41, 2433-2439.

369 Radville, L., Chaves, A., Preisser, E., 2011. Variation in plant defense against invasive

370 herbivores: evidence for a hypersensitive response in eastern hemlocks (Tsuga canadensis). J

371 Chem Ecol 37, 592-597.

372 Rasmann, S., Agrawal, A.A., Cook, S.C., Erwin, A.C., 2009. Cardenolides, induced responses,

373 and interactions between above- and belowground herbivores of milkweed (Asclepias spp.).

374 Ecology 90:2393-2404. Ecology 90, 2393-2404.

375 Robertson, G.P., Coleman, D.C., Bledsoe, C.S., Sollins, P. (Eds.), 1999. Standard Soil Methods

376 for Long-term Ecological Research. Oxford University Press, New York.

377 Rooney, N., McCann, K., Gellner, G., Moore, J.C., 2006. Structural asymmetry and the stability

378 of diverse food webs. Nature 442, 265-269.

379 Rossow, L.J., Bryant, J.P., Kielland, K., 1997. Effects of above-ground browsing by mammals

380 on mycorrhizal infection in an early successional taiga ecosystem. Oecologia 110, 94-98.

381 Ruess, R.W., McNaughton, S.J., 1987. Grazing and the dynamics of nutrient and energy

382 regulated microbial processes in the Serengeti grasslands. Oikos 49, 101-110.

383 Smith, J., Schowalter, T., 2001. Aphid-induced reduction of shoot and root growth in Douglas-fir

384 seedlings. Ecol Entomol 26, 411-416.

385 Smith, S.E., Read, D.J., Harley, J.L., 1997. Mycorrhizal Symbiosis. Academic Press, San Diego

386 CA. 
387 Stadler, B., Müller, T., Orwig, D., 2006. The ecology of energy and nutrient fluxes in hemlock

388 forests invaded by the hemlock woolly adelgid. Ecology 87, 1792-1804.

389 Stadler, B., Müller, T., Orwig, D., Cobb, R., 2005. Hemlock woolly adelgid in New England

390 forests: canopy impacts transforming ecosystem processes and landscapes. Ecosystems 8, 233-

391247.

392 Stadler, B., Solinger, S., Michalzik, B., 2001. Insect herbivores and the nutrient flow from the 393 canopy to the soil in coniferous and deciduous forests. Oecologia 126, 104-113.

394 Veen, G.F., Olff, H., Duyts, H., van der Putten, W.H., 2010. Vertebrate herbivores influence soil

395 nematodes by modifying plant communities. Ecology 91, 828-835.

396 Vessey, J.K., 2003. Plant growth promoting rhizobacteria as biofertilizers. Plant Soil 255, 571-

397586.

398 Wardle, D.A., Bardgett, R.D., Klironomos, J.N., Setälä, H., van der Putten, W.H., Wall, D.H.,

399 2004. Ecological linkages between aboveground and belowground biota. Science 304, 1629-

4001633.

401 Zvereva, E., Lanta, V., Kozlov, M., 2010. Effects of sap-feeding insect herbivores on growth and

402 reproduction of woody plants: a meta-analysis of experimental studies. Oecologia 163, 949-960. 


\section{$404 \quad 7.0$ Figure Legends}

405 Figure 1. Sites in Connecticut and Massachusetts used for the mycorrhizal (Study \#1) and 406 root bacterial abundance (Study \#2) surveys.

407 Figure 2. Mean bacterial abundance (A), mean percent carbon (B), mean percent nitrogen 408 (C), and mean carbon:nitrogen ratio (D) of eastern hemlock fine roots in 10 uninfested hemlock 409 stands and 10 adelgid-infested hemlock stands. 


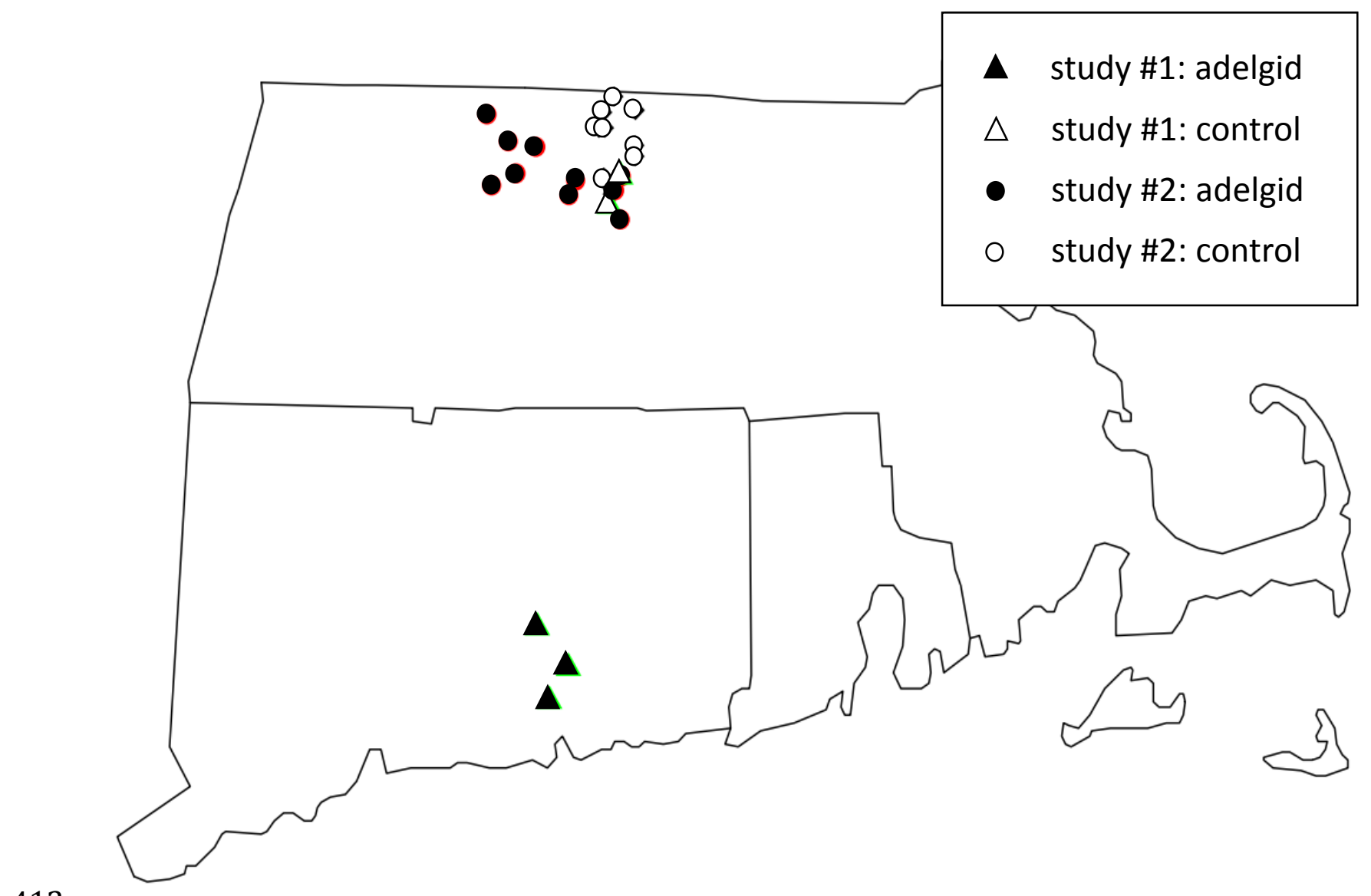

412

413 


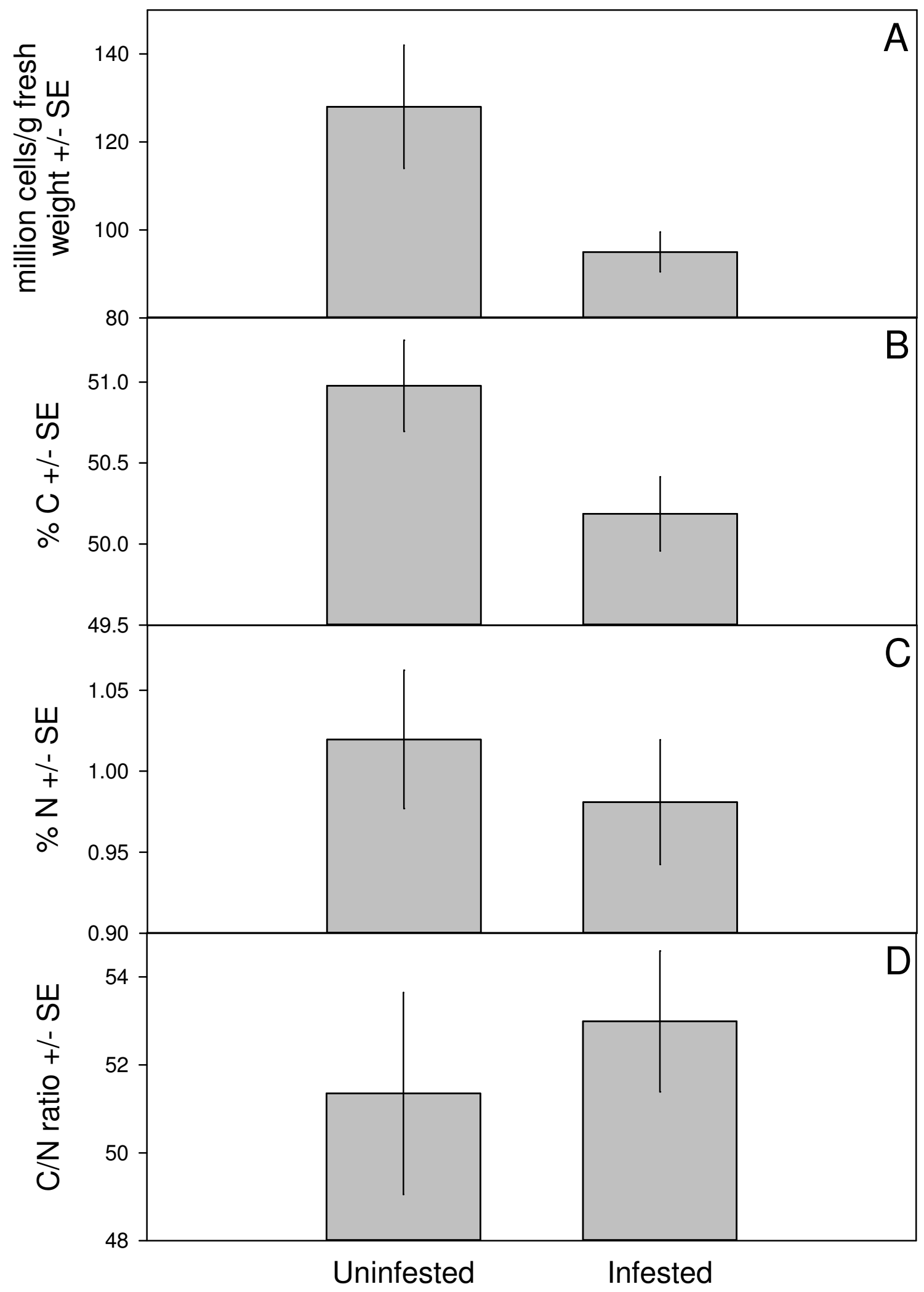

